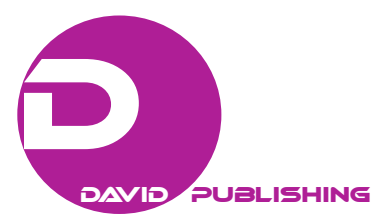

\title{
Financing Difficulties of Small and Medium Enterprises (SMEs) in the West African Economic and Monetary Union (WAEMU) Area
}

\author{
Kokou Adalessossi, Burcu Demirel Utku \\ Akdeniz University, Antalya, Turkey
}

Difficulties in financing small and medium enterprises (SMEs) of the West African Economic and Monetary Union (WAEMU) zone, which is composed of eight member countries, is a very delicate topic and a serious cause for concern, as the SMEs that constitute the pillars of the sub regional economy of this zone, are experiencing difficulties in getting banks and/or other financial institutions to finance their activities. The aim of this paper is to highlight the specific challenges inhibiting SMEs in accessing credit in this area. In accordance with this objective, some questions have been asked as following: Do SMEs have challenges in accessing credit in WAEMU countries? To what extent have these challenges affected their operations? In this light, a quantitative study was conducted among 120 (70 Togo's capital City_Lome and 50 in Mali's capital city_Bamako) SMEs via email using questionnaires. According to the empirical results of this study (performed by statistical descriptive analysis) in which 100 firms responded, 84 of the firms have recourse to bank loans at least once, most of which have faced challenges in mobilizing financial and mortgages guarantees and high interest rates resulting in difficulties in loan repayment; whereas just 16 had never made reliance on loans in the conventional and unconventional banks due to high level of guarantee required by the bank and the phobia of not being able to repay loans with a high interest rate. As recommendations, WAEMU authorities must establish a large sub-regional structure that should have mission to put in place support mechanisms for SMEs through several aspects by creation of agencies in each of the eight countries. This study permits to open eyes for WAEMU' authorities, financial institutions, and banks authorities to find an adequate solution for these problems encountered by SMEs which remain the sub-regional economy's corner stone.

Keywords: difficulty of financing, small and medium enterprises (SMEs), bank, West African Economic and Monetary Union (WAEMU), statistical descriptive analysis

\section{Introduction}

\section{Background}

Small and medium sized enterprises (SMEs) in both developing and developed countries play important roles in the process of industrialization and economic growth, by significantly contributing to employment

Kokou Adalessossi, Ph.D. student researcher in Finance, Faculty of Economics and Business Administration Sciences, Business Administration Department, Akdeniz University, Antalya, Turkey.

Burcu Demirel Utku, associate professor, accounting and finance, Faculty of Economics and Business Administration, Business Administration Department, Akdeniz University, Antalya, Turkey.

Correspondence concerning this article should be addressed to Kokou Adalessossi, Akdeniz University, Dumlupinar Bulvari, 07058 Kampus, Antalya, Turkey. Tel: +905078510893. E-mail: pascaladalessossi@yahoo.fr. 
generation, income generation, and catalyzing development in urban and rural areas (Organisation for Economic Co-operation and Development, 2004). As affirmed by one estimate, Africa and Asia have the majority of their population living in rural areas where small scale enterprises deliver about $20 \%-45 \%$ of full-time employment and 30\%-50\% of rural household income (Haggblade \& Liedholm, 1991). Latin America, which is more urbanized, has an estimated 50 million micro and small-scale enterprises, employing 120 million people (Berger \& Guillamon, 1996).

SMEs constitute about $70 \%$ of total business units in West African Economic and Monetary Union (WAEMU) area and account of more than 50\% of WAEMU's employed labour force (World Bank, 2009). They are often described as efficient and prolific job creators, the seeds of big businesses, and the fuel of regional economic engines. Even in the developed industrial economies, it is the SME sector rather than the multinationals that is the largest employer of workers (Mullineux, 1997). This is also supported by a research done on small businesses in the United States by Charles (2006), which indicated that U.S. small businesses numbered 23 million in 2003, and it employed about half of the private sector work force, and also produces about half of the nation's private sector output.

As part of its economic and social policy development, the governments of the WAEMU countries (Benin, Burkina Faso, Côte d'Ivoire, Guinea-Bissau, Mali, Niger, Senegal, and Togo) have focused on the promotion of private initiative and participatory development. As such, the SME has been identified as one of the essential key lever for development in the sense that the training effects on the rest of the economy in terms of job creation, diversification production, and utilization of productive resources are real. In parallel, a current of thought has gradually developed describing the micro-enterprises not only as a means to fight against poverty, but also as a solution to problems of growth in developing countries such as the area of WAEMU. It is in this perspective that since these two decades, authorities with the support of partners engaged in promoting that category of business.

However, the proportion of SMEs based on their efforts always seems worrying. In fact, these companies face many difficulties that constrain their development. Among which include the problem of accessing to bank financing. Another area of constraint, which tends to block the flow of credit to SMEs, is lack of information. Small business owners most often possess more information about the potential of their own businesses, but in some situations, it can be difficult for business owners to articulate and give detailed information about the business as the financiers want. Additionally, some small business managers tend to be restrictive when it comes to providing external financiers with detailed information about the core of the business, since they believe in one way or the other, information about their business may leak through to competitors (Winborg \& Landstrom, 2000). Aside their unwillingness to disclose information to financiers, SMEs in WAEMU countries (comprising Benin, Burkina, Côte d'Ivoire, Guinea- Bissau, Mali, Niger, Senegal, and Togo) are also faced with the challenge of proper book keeping practices that makes it difficult for financiers who are even willing to assist to do so.

\section{Objective of the Study}

The objective of the study is to highlight the specific challenges inhibiting SMEs in accessing credit in WAEMU countries with a view to proposing some recommendation to help mitigate these challenges.

In pursuance of this objective, the following research questions were administered:

- Do SMEs have challenges in accessing credit in WAEMU' countries? What are they? 
- To what extent have these challenges affected their operations?

- What alternative sources of funding are SMEs resorting to and how viable are these?

\section{Literature Review}

\section{Some SME Definitions}

According to Ward (2005), there is no universal definition for SMEs, since the definition depends on who is defining it and where it is being defined, for example, in Canada, SME is defined as an enterprise that has fewer than 500 employees and small enterprise as one that has less than 100 employees. On the other hand, the World Bank defines SMEs as having no more than 500 employees. SMEs can be defined in two ways: based on the number of employees in an enterprise and/or the enterprises fixed assets.

\section{International Overview}

While the importance of the SME sector and the informal sector are acknowledged internationally, defining an SME is a challenging task, as every country has its own definition. There is no single uniformly accepted definition of a small firm (Storey, 1994). SME definitions can be broadly categorized into two: "economic" and "statistical" definitions. Under the economic definition, a firm is regarded as small, if it meets the following three criteria: (1) It has a relatively small share of their market place; (2) it is managed by owners or part owners, in a personalized way and not through the medium of a formalized management structure; and (3) it is independent in that it is not part of a larger enterprise. The "statistical" definition, on the other hand, is used in three main areas: (1) quantifying the size of the small firm sector and its contribution to GDP, employment, and exports; (2) comparing the extent to which the small firm sector's economic contribution has changed over time; and (3) in a cross country comparison of the small firms' economic contribution. In Table 1, the application for qualitative indicators is shown.

Table 1

\section{Application for Qualitative Indicators}

\begin{tabular}{|c|c|c|}
\hline Category & SMES & Larges Company \\
\hline Management & $\begin{array}{l}\text { - Proprietor entrepreneurship } \\
\text { - Functions-linked personality }\end{array}$ & $\begin{array}{l}\text { - Manager-entrepreneurship } \\
\text { - Division of labor by subject matters }\end{array}$ \\
\hline Personnel & $\begin{array}{l}\text { - Lack of university graduates } \\
\text { - All-round knowledge }\end{array}$ & $\begin{array}{l}\text { - Dominance of university graduates } \\
\text { - Specialization }\end{array}$ \\
\hline $\begin{array}{l}\text { Organization } \\
\text { Sales } \\
\text { Buyer's relationships } \\
\text { Production } \\
\text { Research development }\end{array}$ & $\begin{array}{l}\text { - Highly personalized contacts } \\
\text { - Competitive position not defined and uncertain } \\
\text { - Unstable } \\
\text { - Following the market, intuitive approach }\end{array}$ & $\begin{array}{l}\text { - Highly formalised communication } \\
\text { - Strong competitive position } \\
\text { - Based on long-term contracts } \\
\text { - Capital intensive, economies of scale } \\
\text { - Institutionalised }\end{array}$ \\
\hline Finance & Role of family funds, self financing & $\begin{array}{l}\text { - Diversified ownership structure, } \\
\text { access to anonymous capital market }\end{array}$ \\
\hline
\end{tabular}

Source: United Nations Industrial Development Organization (1999).

The definition of SME by region is shown in Table 2. 
Table 2

Synopsis of SME Definitions by Region

\begin{tabular}{|c|c|c|c|c|c|c|c|c|c|c|c|c|c|}
\hline & & & & & & & & & \multicolumn{3}{|c|}{ BRICS } & \multicolumn{2}{|r|}{$\begin{array}{l}\text { WAEMU } \\
\text { Countries }\end{array}$} \\
\hline & EU & USA & ASIA & EGYPT & GHANA & TURKEY & \multicolumn{2}{|c|}{ BRAZIL } & RUSSIA & INDIA & CHINA & \multicolumn{2}{|l|}{ S AFRICA } \\
\hline & & & & & & & Industrial & commercial & & & & & \\
\hline words & $\begin{array}{l}\text { Small and } \\
\text { Medium } \\
\text { Enterprise }\end{array}$ & $\begin{array}{l}\text { Small and } \\
\text { Medium } \\
\text { Enterprise }\end{array}$ & $\begin{array}{l}\text { Small and } \\
\text { Medium } \\
\text { Enterprise }\end{array}$ & $\begin{array}{l}\text { Small and } \\
\text { Medium } \\
\text { Enterprise }\end{array}$ & $\begin{array}{l}\text { Micro, } \\
\text { Small and } \\
\text { Medium } \\
\text { Enterprise }\end{array}$ & $\begin{array}{l}\text { Small and } \\
\text { Medium } \\
\text { Enterprise }\end{array}$ & $\begin{array}{l}\text { Small and } \\
\text { Medium } \\
\text { Enterprise }\end{array}$ & $\begin{array}{l}\text { Small and } \\
\text { Medium } \\
\text { Enterprise }\end{array}$ & $\begin{array}{l}\text { Small and } \\
\text { Medium } \\
\text { Enterprise }\end{array}$ & $\begin{array}{l}\text { Micro, } \\
\text { Small and } \\
\text { Medium } \\
\text { Enterprise }\end{array}$ & $\begin{array}{l}\text { Small and } \\
\text { Medium } \\
\text { Enterprise }\end{array}$ & $\begin{array}{l}\text { Small and } \\
\text { Medium } \\
\text { Enterprise }\end{array}$ & $\begin{array}{l}\text { Micro } \\
\text { Small and Medium } \\
\text { Enterprise }\end{array}$ \\
\hline \multicolumn{14}{|c|}{ No. of Employees } \\
\hline Micro & $<10$ & 0 & $<5$ & 1 to 4 & Up to 5 & 1 to 9 & Up to 19 & Up to 09 & 0 & 0 & 0 & $<20$ & $<10$ \\
\hline Small & $<50$ & $<100$ & 5 to 50 & 5 to 14 & 6 to 29 & 10 to 49 & 20 to 99 & 10 to 49 & 15 to 100 & 0 & $<300$ & 50 to 99 & 10 to 49 \\
\hline Medium & $<250$ & $<500$ & 51 to 150 & 15 to 49 & 30 to 99 & 50 to 249 & 100 to 499 & 50 to 99 & 101 to 250 & 0 & $\begin{array}{l}300 \\
2000\end{array}$ & 100 to 200 & 50 to 199 \\
\hline \multicolumn{14}{|l|}{ Turnover } \\
\hline Micro & $\$ 3 \mathrm{~m}$ & 0 & $\begin{array}{l}\text { RM } \\
250.000\end{array}$ & 0 & $\$ 10 \mathrm{k}$ & & 0 & 0 & 0 & $<$ Rs 50 m & 0 & $<20$ & $\begin{array}{l}<\text { FCFA } 30 \\
\text { millions }\end{array}$ \\
\hline Small & $\$ 13 \mathrm{~m}$ & 0 & $\begin{array}{l}\text { To }<\text { RM } \\
10 \mathrm{M}\end{array}$ & 0 & $\$ 100 \mathrm{k}$ & & 0 & 0 & $\begin{array}{l}400 \mathrm{~m} \mathrm{RU} \\
\text { to Max }\end{array}$ & $\begin{array}{l}\text { Rs } 50-60 \\
\text { m }\end{array}$ & $<$ y 30 & R 2150k & $\begin{array}{l}\text { FCFA } 30 \text { to } 150 \\
\text { millions }\end{array}$ \\
\hline Medium & $\$ 67 \mathrm{~m}$ & 0 & $\begin{array}{l}\mathrm{RM} 10 \mathrm{M} \\
\text { to RM } 25\end{array}$ & 0 & $\$ 1$ million & & 0 & 0 & $\begin{array}{l}1 \text { B RUB } \\
\max \end{array}$ & $\begin{array}{l}\text { Rs 60-99 } \\
\text { m }\end{array}$ & $\begin{array}{l}\text { Y } 30 \text { to } \\
300 \mathrm{~m}\end{array}$ & $\begin{array}{l}\mathrm{R} 4.5 \text { to } \mathrm{R} \\
50 \mathrm{~m}\end{array}$ & $\leq$ FCFA 1 billion \\
\hline
\end{tabular}

Source: Author's compilation from various sources. 
The abbreviation "SME" occurs commonly in the European Union (EU) and in international organizations such as the World Bank, the United Nations (UN), and the World Trade Organization (WTO). The term "SME" or "SMBs" is predominantly used in the USA. In South Africa, the term is "SMME" for small, medium, and micro-enterprises, and elsewhere in Africa, MSME is used for micro, small, and medium enterprises.

According to Boon (1989), the size of the enterprises employment is the most important criterion used in WAEMU countries. But one must be cautious when defining SMEs based on fixed assets because of the continuous depreciation in the exchange rates, which often makes such definition out-dated. According to United Nations Industrial Development Organization, SMEs in developing countries are based on the number of employees in an enterprise. A small enterprise has five to 19 workers and takes the example of the ubiquitous small shops in the cities, such as hair dressing saloons and chop bars. A medium enterprise has 20 to 99 workers and these include manufacturing firm and exporting companies. But the WAEMU countries Statistical Service considers firms employing between nine and 50 employees and with fixed assets not exceeding $\$ 10,000$ as small scale, while those employing between 50 and 199 employees medium scale category and with fixed assets not exceeding $\$ 500,000$ (excluding land and buildings).

\section{Characteristics of SMEs in WAEMU Countries}

A distinguishing feature of SMEs from larger firms is that the latter have direct access to international and local capital markets whereas the former are excluded because of the higher intermediation costs of smaller projects. In addition, SMEs face the same fixed cost as large scale enterprises in complying with regulations but have limited capacity to market product abroad (Kayanula \& Quartey, 2000). SMEs in WAEMU countries can be categorized into urban and rural enterprises. The former can be subdivided into "organized" and "unorganized" enterprises. Organized ones tend to have employees with a registered office and are mostly solely owned by an individual whereas the unorganized ones are mainly made up of artisans who work in open spaces, temporary wooden structures or at home and employ little or in some case no salaried workers. The major activities within this sector include: soap and detergents, fabrics, clothing and tailoring, textile and leather, village blacksmiths, timber and mining, bricks and cement, beverages, food processing, wood furniture, electronic assembly, agro processing, chemical based products, and mechanics (Liedholm \& Mead, 1987; Kayanula \& Quartey, 2000).

\section{SMEs Contribution to Economic Development and Growth}

The SME sector is considered very important in many economies, because they provide job, pay taxes, are innovative and very instrumental in countries participations in the global market. Beck, Demirguc-Kunt, and Makismovic (2002) stated that SME activity and economic growth are important because of the relatively large share of the SME sector in most developing nations and the substantial international resources from sources like the World Bank group, that have been channeled into the SME sector of these nations. SMEs account for nearly $80 \%$ of the registered businesses in WAEMU countries and therefore play an important role in economic development by providing employment opportunities, opening up new business opportunities, enhancing entrepreneurship, and fostering creativity among many other things.

\section{Constraints Faced by SMEs in Accessing Credit}

Cuevas, Fafchamps, Hanson, Moll, and Srivastava (1993) indicated that access to bank credit by SMEs has been an issue repeatedly raised by numerous studies as a major constraint to industrial growth. A common explanation for the alleged lack of access to bank loan by SMEs is their inability to pledge acceptable collateral. In their view, the current system of land ownership and transfer regulations clearly retards and to some extend 
limits access to formal credit. Firstly, due to lack of clear title to much usable land in WAEMU countries, there is a limited amount of real property that can be put up as collateral. According to the African Development Bank (Mullineux, 2013), the great financing constraints faced by SMEs, especially in accessing bank finance limited their firms' growth opportunities. Firms in sub-Saharan Africa have limited access to external funding. World Bank enterprise surveys show that, on average, only $22 \%$ of enterprises (in sub-Saharan Africa) have a loan or line of credit

\section{Sources of Financing for SMEs}

While not all of the sources that will be discussed here are appropriate for, or accessible to, all of the different types of SMEs, there is a general consensus that two specific theories can help explain the funding choices of entrepreneur or owner-managers:

A number of sources of capital exist but many of them may not be accessible to companies of small and medium sizes.

Friends and relatives. Loans and contributions from friends and relatives are common source of funds, especially for new business, since the financial institutions are reluctant to providing funding for start-up business because of the risk involve. This source of funds, however, bears a potentially dangerous price. Many friends' relatives find it very difficult to stay as passive creditors or investors. They usually try to interfere with policy and operational issues (Kuriloff, Hemphill, \& Cloud, 1993; Longenecker, Moore, \& Petty, 1994). As a remedy to this problem, Kuriloff et al. (1993) recommended the treatment of such loans like bank loans by putting in writing all the terms including interest rates and payment schedule. Hisrich and Peters (1995) made an assertion that commercial banks constitute the most widely used source of debt financing for small companies. This assertion is also supported by longenecker et al. (1994).

Trade credit. Basically, it involves the purchase of goods and services from a supplier on credit. The purchasing firm is given a few days, usually between 30 and 120 days, to settle the debt (Broom, Longenecker, \& Moore, 1983). This type of credit is very important to SMEs for a number of reasons. Broom et al. (1983) and Moyer, McGuigan, and Kretlow (1992) asserted that suppliers are more flexible in dealing with SMEs than the banks.

Personal resources. Again Longenecker et al. (1994) observed that personal savings of the owners and partners of businesses constitutes an important source of funds, particularly in the formative stages of a firm. Personal contributions also help to raise additional funds from other sources. Significant financial commitments made by owners of a company tend to build a lot of confidence among potential investors. Kuriloff et al. (1993) also noted other personal resources apart from personal savings. These include borrowing using one's personal assets, such as house and bonds as collateral.

\section{Importance of Financial Institutions in SME Development}

Finance is the oil for growth. It is indeed the life-blood of the economic system. The financial system is the vessel that carries this life-blood through the economic system.

Patrick (1966) stated in his work that financial institutions play a major role in promoting economic growth by ensuring the availability of cash flow cost credit to potential investors.

\section{Bank Finance for SMEs}

Overview of business finance. Bank lending (debt) is one of the key aspects of business finance. The banking and finance industry provides a range of products and services to all types of businesses from the 
smallest micro to the largest corporate. The common finance option across all business is bank overdrafts (for working capital needs) and term loans (for capital expenditure needs). In addition, there are a number of specialist finance products such as asset backed lending, invoice discounting, factoring, trade finance, vendor finance, and consortium finance.

The credit decision making process. Historically, banks would use judgment in evaluating the creditworthiness of the applicant, drawing from the experience of previous lending decisions. The end result of the evaluation process is to provide a measure of creditworthiness. According to Lewis (1992, p. 3), "creditworthiness is a characteristic of an individual that makes him or her a suitable candidate for the extension of credit, while someone who is not creditworthy is, conversely, unsuited to credit".

This means that the applicant who is creditworthy pays all their obligations as agreed in the credit terms and conditions and those that are non-creditworthy do not. Thus, creditworthiness implies an applicant's ability and willingness to repay. According to Feldman (1997), there is a correlation between the willingness and ability to repay of a firm with that of the owner. It could be argued that the personal history of the owner could be used to determine the repayment prospects of the firm.

\section{Issues and Challenges in Bank Lending}

Relationship lending versus transactional lending. Globally, SMEs are confronted with relatively harsh credit constraints and limited access to finance (Beck et al., 2002; Beck \& Demirguc-Kunt, 2004). According to Baas and Schrooten (2005), due to the limited publicly available information on SMEs, banks are hesitant to provide credit. However, Boots and Milbourn (2002) argued that the lack of information can be compensated by using relationship lending, in which the SME and the bank enters into a long-term relationship that assures the SMEs access to credit and the bank access to soft information.

Information asymmetry. One of the challenging areas in SME lending is "information asymmetry" which arises as a result of the different levels of information held by the bank as well as the SME about the future of the business (Binks \& Ennew, 1996). Berger and Udell (1998) argued that new businesses are the most informationally opaque, on account of their lack of any track record of their business.

\section{Methodology}

\section{Research Method}

To achieve the proposed research objective of highlighting the specific challenges inhibiting SMEs in accessing loans/funding in WAEMU countries, the quantitative research method was adopted, which often is the most efficient and cost-effective research method (Gerhardt, 2004).

\section{Data Collection Techniques}

The data for this study were gathered through the use of primary and secondary data sources. The primary data source for this study involved the use of questionnaire. The questionnaires were sent by email to SME operators and/or owners in Togo and in Mali for first hand information for processing towards answering the research questions. The questionnaire was divided into three sections.

Section A concentrated on the general information on the firms such as: legal structure of the firm, duration of the firm' $s$ activity, sector of the firm, activity of the firm; number of employees of the firm, education level of the firm's employees, repartition of the firm's employees according to the gender, kind of person who manages the firm, education level of the firm's manager, general important problems faced by the 
firm, and importance of expectations from the firm. These questions look to identify the types of SMEs which were concerned in this study, whether or not they were micro, small, or medium enterprises as per the definition given above (Table 2), to find out their sector activities, to discover the educational level of employees and employers involved in these SMEs.

Section B of the questionnaire consisted of various questions geared towards answering the objective of the study. These financial information questions looked at the financing and constraints faced by SMEs when accessing credit, or after benefiting credit, other financing options available to these SMEs, how cheap or expensive the cost of finance is in the opinion of these SMEs among others, how kind of financing the SMEs used, financial planning and management, importance of the terms of credit, and importance of the source of the financing problems.

Section $\mathrm{C}$ of questionnaire of various questions concerns financial organization and approach of solutions to problems encountered. These questions touch principal points as following: existence of finance/funding department in the firm; person who manages the firm's financing/financial activities; financial planning making in the firm; factor that mostly hinders/hampers financial planning; cash-flow management priority in the firm; capital investment criterion; target objectives advantages in financing techniques; and suggestions of solutions for the financial problems met by the firm.

The secondary data were obtained from reviewing journals and literature relevant to the subject matter of this research. Newspaper source and official policy documents of government of WAEMU countries with relevance to the subject were also consulted. The electronic search site (www.google.com) was employed extensively for up-to-date materials on the topic. The primary data formed the crux of this study, because it afforded the opportunity in obtaining at first hand, relevant responses.

\section{Data Collection Instrument}

In view of the nature of the topic, it was realized that a questionnaire would be the main and the most appropriate instrument to use. Questionnaires are an inexpensive way to gather data from a potentially large number of respondents. The researcher gave a serious through to the wording of individual questions. This was done to ensure respondents answer objectively to the questions in the questionnaire. The questions were in the open ended and close ended forms. In the open ended question, the respondents formulated their own answers. In closed format, respondents were forced to choose between several given options. The open ended format allowed exploration of the range of possible terms arising from an issue. It was used where a comprehensive range of alternative choices could not be compiled. The closed or forced choice-format was easy and quick to fill in. It was easy to code, record, and analyze results quantitatively and easy to report results.

\section{Target Population}

SMEs are scattered across the length and breadth of two countries of WAEMU countries with most of them located in the big cities (Lomé (Togo) and Bamako (Mali)) of the countries. These cities were identified to have high concentration of SMEs. In adopting a case study method in a research, the selection of the research site is most important (Yin, 1994). With this in mind, Greater Lomé and Bamako regions were selected for the following reasons.

Firstly, most of the SMEs are located in this area, so are the banks and non-bank financial institution, since these chosen cities are capital cities. With the objectives of the study in mind, selecting this region afforded the researcher the opportunity to contact SME operators who have made numerous contacts with business chamber 
and with different banks for financial support and therefore have a lot of experience to share. Secondly, it was easier for the researcher to reach by email these SMEs operators and because of development of TIC (internet); the SMEs can send the filled questionnaire to the researcher's address without problem.

Choosing any other region would be difficult for the researcher to send the questionnaire to SMEs and it will also be difficult for the SMEs to send back the filled questionnaire to the researcher, because a lot of SMEs operators apart from those in big cities don't have access to internet.

\section{Sample size}

Following WAEMU, SMEs can be classified into: micro enterprise (one to nine workers), small enterprise (10 to 49 workers), and medium enterprise (50 to 199 workers). A sample size of the 120 participants (70 from Lomé and 50 from Bamako Mali's capital city) was targeted for responses. One hundred and twenty questionnaires were sent by the email to the SMEs operators, according to the list that the researcher got from the business chamber of the two countries. Among the 120 questionnaires sent, 100 responses (of which 65 from Togo and 35 from Mali) received represent $83.3 \%$ of the response rate which was deemed to be impressive for this research.

\section{Data Analysis}

The statistical package for social science (SPSS version 13.0) was used to process and analyze the raw data through the means of relative frequencies and graphs; tables and charts after the data was edited for completeness. Shortly, a descriptive statistics was found to be an ideal analysis technique and subsequently used in ascertaining the difficulties that SMEs faced in accessing bank loans.

\section{Methodological Limitations}

The main limitation of the literature review as a study methodology is that it relies on the information which has already been researched (secondary information), and if there is none, then specific questions on the new study might not be adequately answered. Because of these limitations, a literature review is always conducted in preparation for primary research.

Secondly, due to information constraint, a relatively small sample size of 120 SMEs was employed and as such, it limits the extent to which authors can generalize the issues raise. Again, it would have been better to have sample some SMEs in other WAEMU' countries like Benin, Cote d'Ivoire, Guinea, Burkina Faso, Niger, and Senegal to have sample frame generalized. But due to information constraint to get the SMEs list from the business chamber or from some banks of each country and due to the distance constraint between the researcher's actual living country (Turkey) and the area research place, authors could not have travelled to those areas due to the time constraint.

\section{Procedures}

After deciding the target population, a list of SMEs in the capital cities was received from the business chamber of the countries relative for research. Authors got respectfully 100 and 140 lists of SME from Mali's business chamber and Togo's business chamber. Among 100 SMEs numerated, 50 SMEs were chosen as following: 25 SMEs were selected in the first 50 SMEs by selecting those which hold pair numerous $(2,4,6$, $8, \ldots 50)$ and 25 other SMEs were selected by choosing those which hold the impair numerous $(51,53,55$, $57, \ldots 99)$ in the last 50 SMEs. For 140 SMEs, 70 SMEs were selected like following: 35 SMEs were selected in the first 70 SMEs by choosing every impair numerous $(1,3,5, \ldots 69)$ and 35 were selected in the last 70 SMEs by selecting those which numerous were pair $(70,72,74, \ldots 140)$. 
After, contacts have been made to seek the consent of all these SMEs to be part of this research; the numbers of 120 SMEs were therefore arrived at. All the SMEs that agreed to be part were subsequently contacted and given a brief about what the study sort to achieve through the means of telephone. After getting the required number for the study, the questionnaires were sent via email. The receivers were then given three weeks to complete the questionnaires, as this gave them ample time in giving out the right responses.

\section{Empiricals Results and Discussion}

This section consists of the data presentation and analysis of all the findings of the research.

\section{General Information}

Legal structure SME's existence activities duration/sector activities and activities of SME. From Table 3 concerning the legal structure, it shows that out of 100 respondents, $48 \%$ have had their business registered as sole proprietorship, 27\% have had their business registered as limited Liabilities Companies, and $10 \%$ have had their business registered as anonym companies, while $9 \%$ and $6 \%$ have had their business registered respectively as limited partnership and general partnership. The result shows that the most registered business in WAEMU' area was sole proprietorship and limited liability companies totalizing both $75 \%$ of the registered business.

Table 3:

Characteristics of SMEs

\begin{tabular}{|c|c|c|c|}
\hline & Frequency & Percent & Cumulative Percent \\
\hline \multicolumn{4}{|l|}{ Legal structure of SME's } \\
\hline Sole proprietorship & 48 & 48.0 & 48.0 \\
\hline General Partnership (GP) & 6 & 6.0 & 54.0 \\
\hline Limited Partnership (LP) & 9 & 9.0 & 63.0 \\
\hline Limited Liability Company (LLC) & 27 & 27.0 & 90.0 \\
\hline Anonym Company (AC) & 10 & 10.0 & 100.0 \\
\hline Total & 100 & 100.0 & \\
\hline \multicolumn{4}{|l|}{ SME's existence long/activities duration } \\
\hline $1-3$ years & 32 & 32.0 & 32.0 \\
\hline $4-10$ years & 46 & 46.0 & 78.0 \\
\hline $11-25$ years & 15 & 15.0 & 93.0 \\
\hline 26 years and over & 7 & 7.0 & 100.0 \\
\hline Total & 100 & 100.0 & \\
\hline \multicolumn{4}{|l|}{ Sector activity of the SMEs } \\
\hline Artisanal & 10 & 10.0 & 10.0 \\
\hline Service & 24 & 24.0 & 34.0 \\
\hline Fabrication/production & 19 & 19.0 & 53.0 \\
\hline Commerce & 47 & 47.0 & 100.0 \\
\hline Total & 100 & 100.0 & \\
\hline \multicolumn{4}{|l|}{ Activities of the SMEs } \\
\hline Purchase and sell & 48 & 48.0 & 48.0 \\
\hline Fabrication/production (including artisanal sector), & 29 & 29.0 & 77.0 \\
\hline the service sector & 23 & & 100.0 \\
\hline Total & 100 & & \\
\hline
\end{tabular}

Source: SPSS 20. 
From Table 3 cncerning SME's existence activities duration, $46 \%$ of the respondents (SME) of the total 100 respondents started their business activities four to 10 years ago, 32\% started their business activities one to three years ago, while 15\% started their business activities 11 to 25 years ago and $7 \%$ started their activities over 26 years ago. The result shows that $78 \%$ of the respondents have not exceeded 10 years of business activities

Concerning sector activity of SMEs, out of the total 100 respondent, $47 \%$ are involved in the commerce sector, $24 \%$ in the service sector, $19 \%$ in the production sector, while only $10 \%$ of them are involved in the artisanal sector. Through this result, it is observed that, $90 \%$ of SMES in WAEMU' area are concentrated in the three principal sectors: commerce, service, and production of the total 100 respondents.

From the Table 3, concerning activities; out of 100 respondents, $48 \%$ are involved in the purchase and sell activities, $29 \%$ are involved in fabrication/production (including artisanal sector), while $23 \%$ are involved in the service sector. For all intent and purpose sectors, all the key sectors of the economy were captured in the sample.

Problems faced generally by SMEs. The aim of this is to find out the most important problem generally encountered by the business owners/managers in their activities by ranking the problems in order of importance. According to the result in Figure 1, financing problems were ranked as the major problems with 450 scores that business owners/ managers generally meet in their activities. It was followed by the market as the second major problems. Bureaucracy, R\&D, and production problems were ranked respectively as the third, fourth, and fifth major problems with the scores as presented in the figure below. This result reinforces the theory by Cuevas et al. (1993) where they indicated that access to bank credit by SMEs has been an issue and continues to be raised by numerous studies as a major constraint to growth.

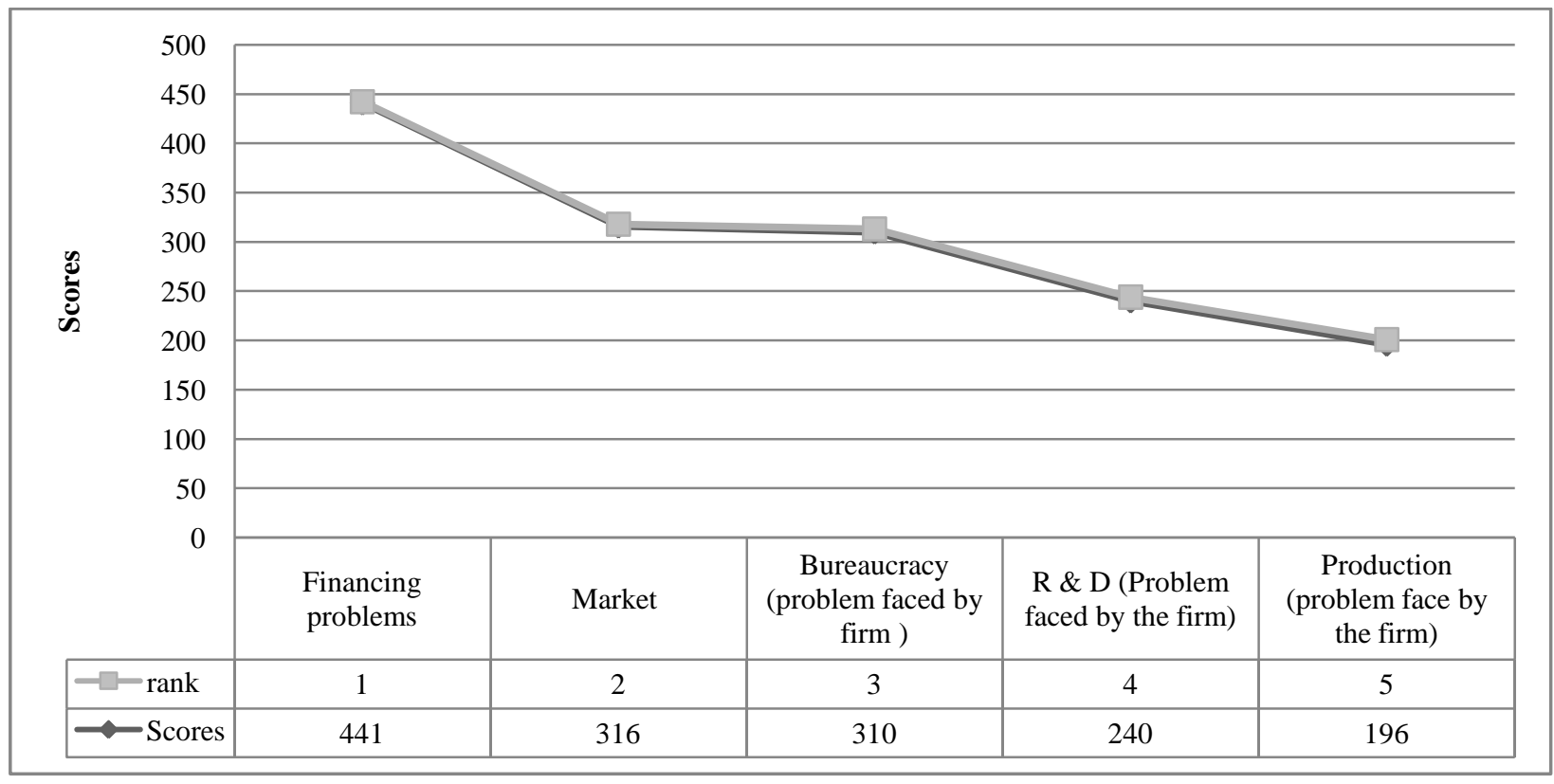

Figure 1. Importance of major problems faced by SMEs, Source: Author's survey.

\section{Financial Information: Financing and Eventual Problems Faced by SMEs}

SME's bank loans application since its activities carrying out. The aim of this objective is to identify which are SMEs that during that their activities have or have not applied for bank loans. This was done by 
using pie chart to summarize answers from respondents. From Figure 2 below, $86 \%$ of respondents, during their activities have applied for bank loan, whereas $16 \%$ of total respondents have never applied for bank loans. The reasons given by ones and others are the high level of guarantees asked by bank, the fear to take bank loan for risk to not be able to refund due to the high level of the loans interest rate, the good financial performance of the firm, the liquidity of treasury, and the sufficiency of the equity.

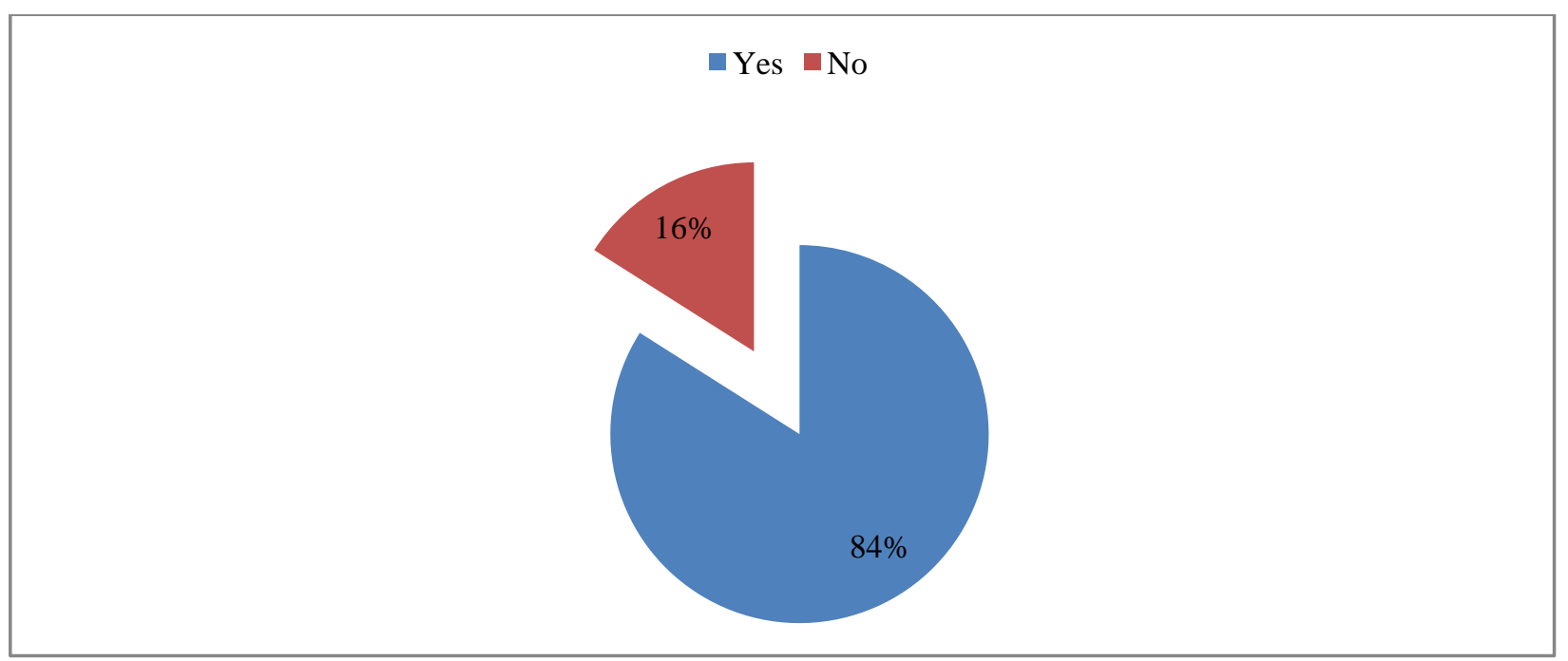

Figure 2. SME's loan application. Source: Author's survey.

Reasons or cause of the loan(s) rejection by bank. This seeks to find out which are the fundamental reasons why SME's applications for bank loans are rejected by the banks. A number of reasons that explained why the SME's are unsuccessful in accessing finance from their banks, according to Table 4 below, low level/lack of guarantees, low level or lack of the firm's financial performance, and low level of the firm account in the bank were provided by the firm. These include size of the business, lack of collateral security, high interest rate, and high transactional cost and mismanagement. Out of 33 respondents, $42.4 \%$ of them have not been granted loans due to the lack or low level of guarantees provided, while $39.4 \%$ of the respondents have been unsuccessful in accessing finance from their bank, due to the low level/lack of the firm's financial performance. Some (12.1\%) of them were due to mismanagement and only $6.1 \%$ of the remaining respondents for the very low level of their firm's account in the bank. This indicates that the most important reasons of not accessing finance from bank were lack of guarantees, problems of financial performance, and mismanagement of the firm. These reasons represent $93.1 \%$ of total respondents. The origin of reasons is caused by the small size of the firm, the lack of collateral, lack of information on the future of the firm, and the lack of the relationship between bank and SMEs. This confirms the founding of Beck et al. (2002) and Beck and Demirguc-Kunt (2004) that, globally, SMEs are confronted with relatively harsh credit constraints and limited access to finance. According to Baas and Schtooten (2005), due to the limited publicly available information on SMEs, banks are hesitant to provide credit. However, Boots and Milbourn (2002) argued that the lack of information can be compensated by using relationship lending, in which the SMEs and the bank enters into a long-term relationship that assures the SMEs access to credit and the bank access to soft information.

\section{Types of Guarantees/Collateral Required by the Bank}

This seeks to find out what are the types of guarantees that SMEs are asked by banks. The result in Table 5 
shows that $63.1 \%$ representing 53 of the total 84 respondents that have made request for loans were asked mortgage and financial guarantees by their banks, whereas $35.7 \%$ of them were asked mortgages guarantees. Meanwhile, only $1.2 \%$ representing 1 of the total 84 respondents confirmed to be asked only financial guarantees. This analysis indicates that in WAEMU area, the most required guarantees from SMEs by banks are mortgages and financial guarantees whose value are greater than $100 \%$ of the credits.

Table 4

Reasons of Non-beneficiary of Credit

\begin{tabular}{llccrr}
\hline & & Frequency & Percent & Valid Percent & Cumulative Percent \\
\hline Valid & Mismanagement of the firm & 4 & 4.0 & 12.1 & 12.1 \\
& Very low level of the firm account in the bank & 2 & 2.0 & 6.1 & 18.2 \\
& Low level/lack of the firm's financial performance & 13 & 13.0 & 39.4 & 57.6 \\
& Low level/lack of guarantees provided by the firm & 14 & 14.0 & 42.4 & 100.0 \\
& Total & 33 & 33.0 & 100.0 & \\
Missing & System & 67 & 67.0 & & \\
Total & & 100 & 100.0 & & \\
\hline
\end{tabular}

Source: Survey Field (2014).

Table 5

Types of Guarantees Required by Bank

\begin{tabular}{llrrrr}
\hline & Frequency & \multicolumn{2}{c}{ Valid Percent } & Cumulative Percent \\
\hline Valid & Mortgages guarantees & 30 & 30.0 & 35.7 & 35.7 \\
& Financial guarantees & 1 & 1.0 & 1.2 & 36.9 \\
& Mortgage and financial guarantees & 53 & 53.0 & 63.1 & 100.0 \\
& Total & 84 & 84.0 & 100.0 & \\
Missing & System & 16 & 16.0 & & \\
Total & 100 & 100.0 & & \\
\hline
\end{tabular}

Source: Survey Field (2014).

All this contributes in hindering most SMEs' owners/managers who wish to apply for loans from these banks.

\section{SMEs Major Sources Loans}

This intends to identify the major sources of loans of the SMEs, by which the participants ranked the sources in order of importance. The Figure 3 shows that commercial bank, ranked in the first position, was the major sources of loans of SMEs, followed by tontine/family; microfinance institution /micro credit were ranked respectively in the second; and third position is the major sources of loans of SMEs while investment bank, foreign financial banks, and leasing companies constitute respectively as shown by Figure 3 below the fourth, fifth, and sixth major sources of loans of SMEs. Through this result, it clearly shows that apart from commercial bank, SMEs have other alternatives financing loans from tontine, family, and microfinance institution. The latter offers SMEs flexible terms of loans that are not done by classic banks.

\section{Importance of Problems Faced by the SMEs in Obtaining Short-term Loan}

The objectives is to find out the most important problems faced by SMEs owners/mangers in obtaining short term loans from banks by ranking the problems in order of importance. Figure 4 shows that, for the 51 
respondents who had access to banks loans, the most important problems they had faced are as follows: The difficulty to put together the guarantees asked by banks was ranked in first position with 222 scores; the high level of the loans interest rate with 211 scores was ranked second. Difficulties in providing financial information (balance sheet and income statement), too much bureaucracy in obtaining credit, and limitation of the loan amount by the bank because of the small/medium size of the firm, were respectively ranked as the most third, fourth, and fifth with 124, 109, and 106 scores.

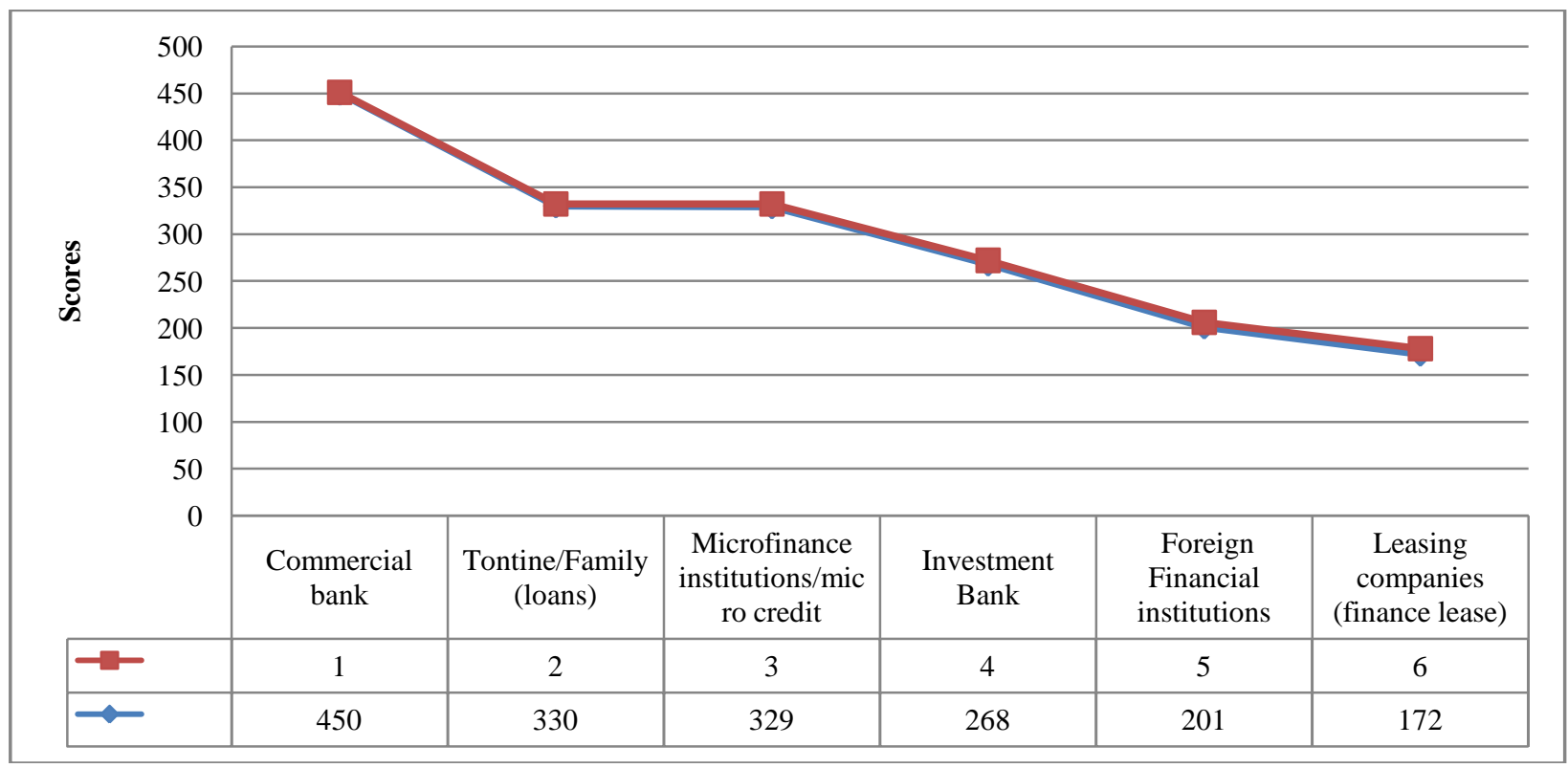

Figure 3. Major sources of SMEs loans. Source: Author's survey.

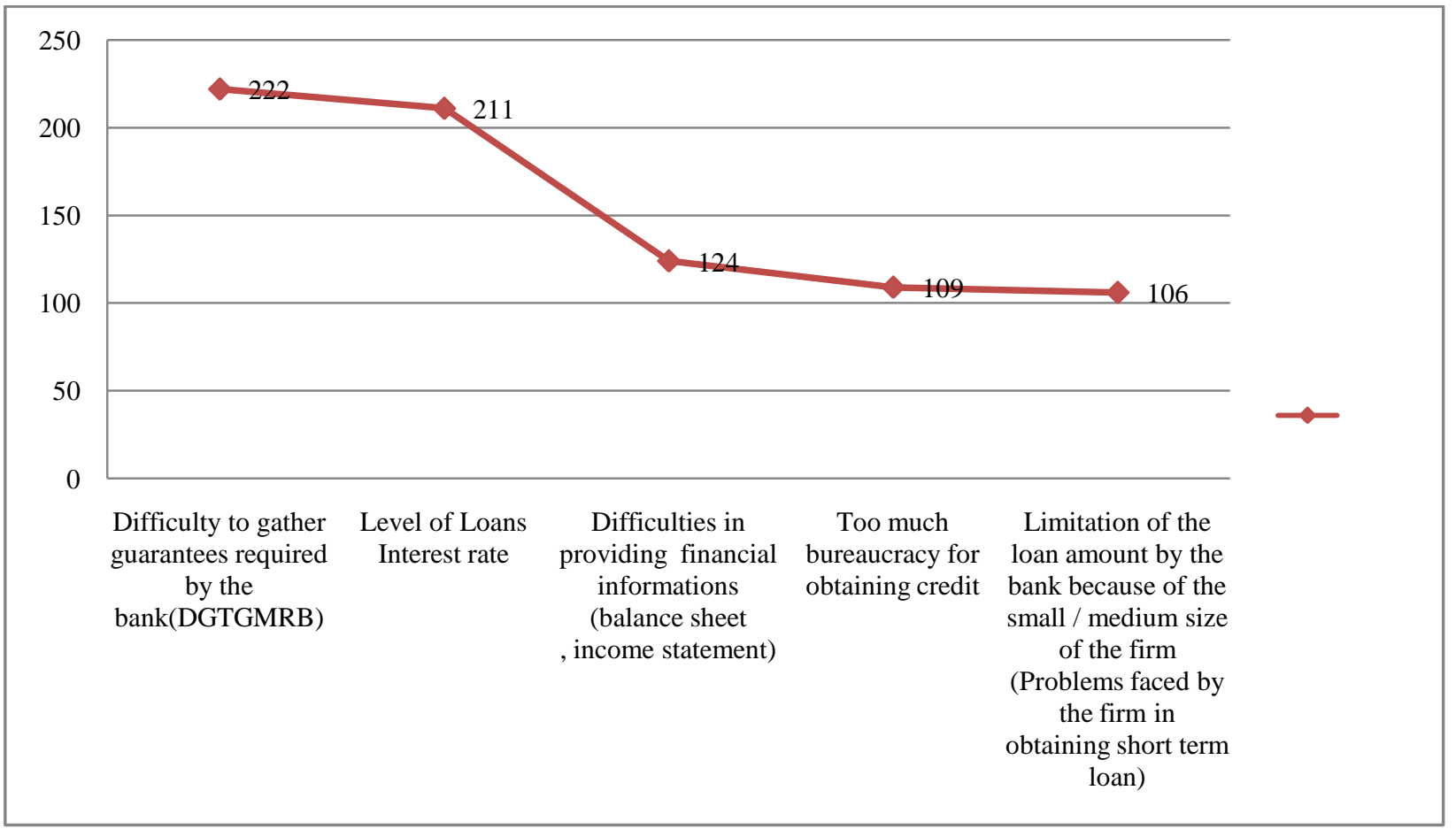

Figure 4. Importance of problems faced by SMEs in obtaining short terms loans. Source: Author's survey. 
It is observed through this result that the most important problems faced by SMEs for the short term loans is the difficulty of putting together the guarantees/collateral required by banks. Beside this, the second important problem was the high level of the interest rate.

Importance of problems that faces the SMEs in obtaining medium/long-term loan. Figure 5 shows that for the 51 respondents that had access to bank loans, the high interest rate of credit investment was the most important problems they had faced in obtaining medium/long term loans. Besides this, the second most important problem they had faced was the difficulty of putting together the guarantees required by the bank. This indicates that, in WAEMU area, the most important problems faced by SMEs' owners/managers were the high level of interest rate and difficulty to put together the guarantees asked by bank.

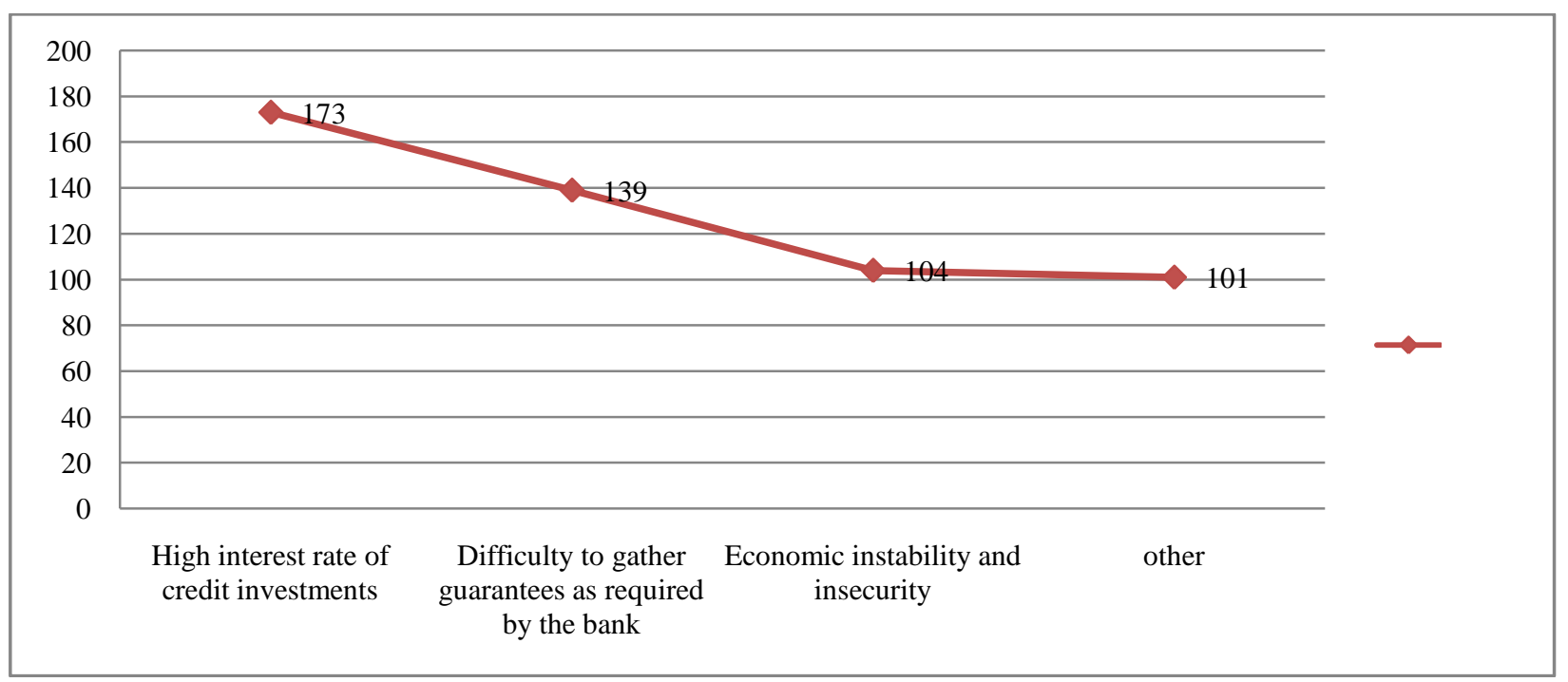

Figure 5. Importance of the problems faced by SMEs in obtaning long terms loans. Source: Author's survey.

Principal reason for some SME to not making recourse to bank credit. The aim of this is to find out the principal reason of the SMEs that did not ask loans from banks. The result on of this survey in Table 6 shows that, $43.8 \%$ representing seven of the total 16 respondents did not make recourse to the bank loans, due to the high level of guarantees required by bank; $25 \%$ of them didn't make recourse to bank loans, due to the fear to take bank loan, for risk of not being able to refund it due to the high interest rate, whereas $18.3 \%$ of them didn't make recourse to bank loans because of the good financial performance of their businesses. For the two remaining respondents, one due to the liquidity of the firm treasury and the other due to the sufficiency of the firm equity, they did not make request for bank loan. This indicates that SMEs in WAEMU for principal reasons like the high level of bank's guarantees and the fear of taking bank loans due to the high level of interest rate did not make recourse to bank loans.

The most major source of the eventual financial problems of the last three months faced by SMEs. The objective is to find out the major source of the eventual financial problems encountered by the firms in the three last months. Table 7 shows that $24 \%$ of respondents representing 14 out of the total of 100 SMEs faced the problems of high loan interest rate, $21 \%$ of them encountered problems of delays in the loans payments, $18 \%$ of them had met decrease or fluctuation of sales problems, $14 \%$ of them had faced the problems of lack of equity, $13 \%$ of them have faced to the problem of a high salary of the firm director, and the remaining respondents representing $10 \%$ out of the total 100 respondents had faced with problems of loss of clients. This 
indicates that in the WAEMU area, SMEs often faced with the major financial problems like the high interest rate and the delays in their loans payment.

Table 6

Obtained Loans Used for Anything Other Than the Intended Purpose by the Bank

\begin{tabular}{llcccc}
\hline & & Frequency & Percent & Valid Percent & Cumulative Percent \\
\hline Valid & Financial performance of the firm & 3 & 3.0 & 18.8 & 18.8 \\
& Our treasury is still over liquid & 1 & 1.0 & 6.3 & 25.0 \\
& The sufficiency of equity & 1 & 1.0 & 6.3 & 31.3 \\
& Fears to take bank loan for risk to not be able to & 4 & 4.0 & 25.0 & 56.3 \\
& refund due to the high level of interest rate & 7 & 7.0 & 43.8 & 100.0 \\
& The high level of guarantees asked by banks & 16 & 16.0 & 100.0 & \\
& Total & 84 & 84.0 & & \\
Missing & System & 100 & 100.0 & & \\
\hline
\end{tabular}

Source: Survey Field (2014).

Table 7

Most Important Source of Eventual Financial Problems Of the Last Three Months Faced by SMEs

\begin{tabular}{llcccc}
\hline & Frequency & Percent & Valid Percent & Cumulative Percent \\
\hline Valid & Loss of clients & 10 & 10.0 & 10.0 & 10.0 \\
& Delays in the loans payment & 21 & 21.0 & 21.0 & 31.0 \\
& Decrease or fluctuation of sales & 18 & 18.0 & 18.0 & 49.0 \\
& lack of equity & 14 & 14.0 & 14.0 & 63.0 \\
Loans interest rates very high & 24 & 24.0 & 24.0 & 87.0 & 100.0 \\
High salary of the director & 13 & 13.0 & 13.0 & 100.0 & \\
Total & 100 & 100.0 & &
\end{tabular}

Source: Survey Field (2014).

\section{Financial Information: Financial Organization and Approach Solution to Problems Encountered}

The person who manages the SME's financing/ financial activities. Table 8 reveals that $45 \%$ of respondents out the total 100 respondents who are managing SMEs' financial activities were firm's owners, 35\% of them were directors or chief accountants, whereas $19 \%$ are professional manager. Only $1 \%$ of them constituted any staff who managed the financial activities of their firm. This shows that SMEs' owners deals with any service in their business, because of the small size and the lack of means to recruit someone to deal with the financial activities.

Table 8

Person Who Manages SMEs' Financial Activities

\begin{tabular}{llrrrr}
\hline & Frequency & Percent & Valid Percent & Cumulative Percent \\
\hline Valid & Firm owner & 45 & 45.0 & 45.0 & 45.0 \\
& Director/Chief accountant & 35 & 35.0 & 35.0 & 80.0 \\
& Any staff & 1 & 1.0 & 1.0 & 81.0 \\
& Finance manager & 19 & 19.0 & 19.0 & 100.0 \\
& Total & 100 & 100.0 & 100.0 & \\
\hline
\end{tabular}

Source: Survey Field (2014). 
Financial planning in the SMEs. This seeks to find out if respondents do or do not do financial planning in their businesses. In Table 9, the result from the survey fields shows that $83 \%$ of respondents representing 83 of the total 100 respondents did not do financial planning in their businesses. However, only $17 \%$ of them (12\% were doing short term financial planning and 5\% the long term financial planning) have done financial planning in their businesses. From this result, it can be said that in WAEMU area, only few of SMEs' owners/managers do financial planning in their firms. This can be the reason of the high level of guarantees and high level of loan interest rate required by banks, due to the lack of information about the future of their firms.

Table 9

Financial Planning in the SMEs

\begin{tabular}{llrrrr}
\hline & Frequency & Percent & Valid Percent & Cumulative Percent \\
\hline Valid & Yes, in short terms & 12 & 12.0 & 12.0 & 12.0 \\
& Yes, in long term & 5 & 5.0 & 5.0 & 17.0 \\
& No & 83 & 83.0 & 83.0 & 100.0 \\
& Total & 100 & 100.0 & 100.0 & \\
\hline
\end{tabular}

Source: Survey Field (2014).

\section{Factor That Mostly Hinders/Hampers SME' Financial Planning}

The aim is to find out the most important factors that hamper the financial planning in the businesses. The result in Table 10 shows that $31.3 \%$ of respondents represent 26 of the total 83 respondents who have not done financial planning in their firm; according to them, the major factor that hampers their financial planning was the lack-cash budget. According to $28.9 \%$ of them, the most important factor that had hindered this was the lack of qualified personnel, $19.3 \%$ of the respondents attributed this obstacle to the uncertainty of exchange and interest rate, $14.5 \%$ of the respondents said that the high inflation was the main factor that hampered them from making a financial planning, while the remaining $6 \%$ of the respondents attributed it to the political and economic instability. The latter respondents were the respondents from Bamako (Mali) that had passed through the political instability recently.

Table 10

Factor Mostly Hampers SME's Financial Planning

\begin{tabular}{llcccc}
\hline & & Frequency & Percent & Valid Percent & Cumulative Percent \\
\hline Valid & The uncertainty of exchange and interest rate & 16 & 16.0 & 19.3 & 19.3 \\
& High inflation & 12 & 12.0 & 14.5 & 33.7 \\
& Lack of cash budgeted & 26 & 26.0 & 31.3 & 65.1 \\
& Lack of qualified personnel & 24 & 24.0 & 28.9 & 94.0 \\
& The political and economic instability & 5 & 5.0 & 6.0 & 100.0 \\
& Total & 83 & 83.0 & 100.0 & \\
Missing & System & 17 & 17.0 & & \\
\hline
\end{tabular}

Source: Survey Field (2014).

It is observed in the above table that the major factor that had hindered financial planning in the SMEs in WAEMU area were the lack of cash budget, the lack of qualified personnel, the uncertainty of exchange, and interest rate and high inflation, while only $6 \%$ of respondents had the political and economic instability as the main factor. 
The most suggestion for solution for the financial problems that meets the SME. The aim of this is to find out what is the principal suggestion for solution that can help the firm in solving their financial difficulties. The result in Table 11 below shows that $30 \%$ of the total 100 respondents suggest that incentives of SMEs should be created in WAEMU area, 24\% of them suggest that conditions of financial and mortgages guarantees should be lowered, $21 \%$ of them propose the assistance in advising from expert organizations, while $18 \%$ respondents suggest that loans interest rate should be reduced and $7 \%$ respondents propose as a solution for the financial problems such as the creation of the regional market. This indicates that, incentives for SMEs, decrease of financial and mortgages guarantees conditions, assistance in advising from expert organizations, all from $93 \%$ of respondents, were the major solution that can help firms in resolving their financial problem in WAEMU area.

Table 11

Most Suggestion of Solution for the Financial Problems That Meets the SMEs

\begin{tabular}{llcccc}
\hline & Frequency & Percent & Valid Percent & Cumulative Percent \\
\hline Valid & Regional market should be created & 7 & 7.0 & 7.0 & 7.0 \\
& $\begin{array}{l}\text { Incentives for SMEs should be } \\
\text { created/increased }\end{array}$ & 30 & 30.0 & 30.0 & 37.0 \\
& Assistance in advising of expert organizations & 21 & 21.0 & 21.0 & 58.0 \\
& Loan interest rate should be reduced & 18 & 18.0 & 18.0 & 76.0 \\
Conditions of financial and mortgages & 24 & 24.0 & 24.0 & 100.0 \\
& guarantees should be lowered & 100 & 100.0 & 100.0 & \\
Total &
\end{tabular}

Source: Survey Field (2014).

Position of the respondents. From Table 12 below, out of 100 respondents of this survey, $49 \%$ were firm owner, $37 \%$ respondents were manager/director, while $14 \%$ respondents were other personnel in the firm. It indicates that $86 \%$ of the respondents that got involved in this survey were firm owner and manager/director. This gives the proof how much their answers are sincere and reliable, because they know and master well all the problems encountered by their firms.

Table 12

Position of Respondents

\begin{tabular}{llllll}
\hline & & Frequency & Percent & Valid Percent & Cumulative Percent \\
\hline Valid & Firm owner & 49 & 49.0 & 49.0 & 49.0 \\
& Manager/Director & 37 & 37.0 & 37.0 & 86.0 \\
& Other & 14 & 14.0 & 14.0 & 100.0 \\
& Total & 100 & 100.0 & 100.0 & \\
\hline
\end{tabular}

Source: Survey Field (2014).

\section{Conclusions and Recommendation}

\section{Conclusions}

The theme of this study is sorting to highlight difficulties faced by these SMEs in accessing credit from the financial institution to operate and grow their businesses in order to achieve their goal.

Based on the responses received through the questionnaires sent, it became evident that SMEs in WAEMU 
like most SMEs in other countries are faced with major challenges in accessing and after accessing credit from banks. The findings of the study show that, the problems of guarantees and higher interest rate were the major causes to financing difficulties encountered by SMEs in WAEMU. This study that concerns an important sector as finance is a remarkable contribution both for the different actors involved in the financing process for all economic agents in general. More, this study is the first concerning the whole WAEMU area and will contribute largely to the literature review and will be useful for the future researcher based on the same field. Finally, this research focusing on SMEs, including their relationships with financial institutions will highly contribute to the liberalization of the sector.

\section{Recommendation}

Based on the findings of the research, the following recommendations were made:

(1) Banks should create a service or department solely dedicated to SMEs activities in order to better understand and boost their services appropriate to this type of firms, according to their business sectors through the following strategies: put in place a strategy of proximity to the SMEs by sensitization and promotion of the culture of bank credit/loan use in order to grow their businesses, while making a pointed and specific insight on the procedures and conditions of applying, obtaining, and repaying of loans, and also providing them wise advice about the company management in general, especially about the management of their finances in particular. This rapprochement of banks to SMEs would create a new or strengthen the confidence that existed between them (relational capital) and therefore would allow banks to better know the SMEs in all aspects. Henceforth, banks can adapt to SMEs' loans demands with flexible conditions for granting (low level of guarantees and interest rate) loans, because they shall know their customers (SMEs) from the trust relationship that is established between them.

(2) Also still with the perspective of strengthening initiatives of financing SMEs' by the banks, community central bank of eight countries (BCEAO) must review and implement a policy bonus rates (policy rates) to grant loans to banks, so that they can in turn do the same actions on SMEs which remain the safety valve for the sub-regional economy.

(3) WAEMU should establish a large sub-regional structure which should have a mission to support mechanisms for SMEs by creating agencies in each of the eight countries covering several aspects as followed: establish a sub-regional structure dedicated solely to finance SMEs with flexible, specific, and adaptable terms for each category of SMEs; establish a technical support structure for SMEs through training, assistance, or capacity building of business leaders or entrepreneurs based on good management and business growth through suitable mechanisms for investments; establish an efficient and flexible system of regional guarantees for SMEs beside banks and institutions involved in their financing; establish a regional system of incentives and rewards for high performance SMEs in order to motivate them to keep continuing the same performance in the future.

(4) Moreover, it is imperative that the sub-regional organization strengthen or create effective and flexible regional markets for SMEs' products and/or services in order to make them more competitive. To strengthen the mission of the sub-regional structure, banks, and other financial institutions, each state may put in place policies for the development of SMEs by establishing bonus system, reductions of financial taxes on banks or the establishment of guarantees structures for SMEs in view to strengthen those that existed before but with very flexible terms allowing a wide number of SMEs to benefit them 


\section{References}

Baas, T., \& Schrooten, M. (2005). Relationship banking and SMEs. A theoretical analysis. Retrieved from http//www.diw.de/sixcms/detail.php/43500

Beck, T., \& Demirgiic-Kunt, A. (2004). SMEs, growth and poverty: Do pro-sme policies work (Public Policy for the Private Sector, February 2004, Note No. 268).

Beck, T., Demirguc-Kunt, A., \& Makismovic, V. (2002). Financial and legal constraints to firm growth: Does size matter (World Bank Policy Research Working Paper No. 2784).

Berger, A. N., \& Udell, G. F. (1998). The economics of small business finance: The Roles of private equity and debt markets in the financial growth cycle. Journal of Banking and Finance, 22, 613-673.

Berger, M., \& Guillamon, B. (1996). Micro enterprise development in Latin America-A view from the inter American development bank. Small Enterprise Development, 7(3), 4-16.

Binks, M. R., \& Ennew, C. T. (1996). Financing small firms. In P. Burns, \& J. Dewhurst (Eds.), Small business and entrepreneurship. London: Macmillan.

Boon, E. K. (1989). Women in SMEs: An African example. Courier, 115, 74-76.

Boots, A. W. A., \& Milbourn, T. (2002). Credit ratings as coordination mechanism (CEPR Discussion Paper).

Broom, H. N., Longenecker, J. G., \& Moore, C. W. (1983). Small business. Cincinnati: South-West Publishing Co..

Charles, O. (2006). Banking and SME financing in the United States. Retrieved from http//www.smmeresearch.co.za/.../Banking\%20and\%20SMME\%20Financing

Cuevas, C., Fafchamps, M., Hanson, R., Moll, P., \& Srivastava, P. (1993). Case studies of enterprise finance in Ghana (Final report, Regional Program on Enterprise Development, The World Bank).

Feldman, R. (1997). Credit scoring and small business loans. Retrieved from http//:minneapolisfed.org

Gerhardt, S. (2004). The automotive industry in Eastern Central Europe (Economics and Research Department, IKB Deutsche Industriebank AG, Dusseldorf).

Haggblade, S., \& Liedholm, C. (1991). Agriculture rural labor markets and the evolution of rural nonfarm economy. Proceedings from 21 st Conference of International Association of Agricultural Economists, Tokyo, Japan.

Hisrich, R. D., \& Peters, M. P. (1995). Entrepreneurship: Starting, developing, and managing a new enterprise (3rd ed.). Retrieved from http://www.gemconsortium.org/download/1322827631223/GEM\%20SA\%202009\%20-

Kayanula, D., \& Quartey, P. (2000). The policy environment for promoting small and medium-sized enterprises in Ghana and Malawi, finance and development research programme (Working Paper Series Paper No. 15, IDPM, University of Manchester).

Kuriloff, A. H., Hemphill, J. M., \& Cloud, D. (1993). Starting and managing the small business (3rd ed.). New York: McGraw-Hill, Inc..

Lewis, E. M. (1992). An introduction to credit scoring. San Rafael: Athena Press.

Liedholm, C., \& Mead, D. C. (1987). Small scale industries in developing countries: Empirical evidence and policy implications (MSU International Development Paper. No 9, Michigan State University).

Longenecker, J. G., Moore, C. W., \& Petty, J. W. (1994). Small business management: An entrepreneurial emphasis. Cincinnati: South-Western.

Moyer, R. C., McGuigan, J. R., \& Kretlow, W. J. (1992). Contemporary financial management (5th ed.). St Paul: West Publishing Company.

Mullineux, A. (1997). Financial innovation, money, banking and financial fragility in the UK. In B. Schachter (Ed.), Derivatives, regulation, and banking (pp. 263-285). North Holland: Finance, Investment and Banking Series, Publishing Company.

Mullineux, A. (2013). Enterprise financing: Lessons for Sub-Saharan Africa. Proceedings from a September 2012 report for the $A F D B$ at an African Finance Journal conference.

Organisation for Economic Co-operation and Development. (2004). Promoting entrepreneurship and innovative SMEs in a global economy. Proceedings from the 2nd OECD conference of ministers responsible for small and medium-sized enterprises (SMEs), Istanbul, Turkey.

Patrick, H. (1966). Financial development and economic growth in underdeveloped countries. Economic Development Cultural Change, 14, 174-189.

Storey, D. J. (1994). Understanding the small business sector. London: Routledge. 
United Nations Industrial Development Organization. (1999). SME cluster and network development in developing countries. Retrieved from http://www.abj.org.jo/AOB_Images/633547381649218750.pdf

Ward, J. L. (2005). Perpetuating the family business: 50 lessons learned from long lasting, successful families in business. New York: Palgrave Macmillan.

Winborg, J., \& Landstrom, H. (2000). Financial bootstrapping in small businesses: Examining small business managers' resource acquisition behavior. Journal of business venturing, 16, 235-254

World Bank. (2009). Doing business 2010. Retrieved from http://www.ifc.org/msmecountryindicators

Yin, R. K. (1994). Case study research: Design and methods (2nd ed.). Thousand Oaks: Sage. 